\title{
Review on Impact of Biofouling in Aquafarm Infrastructures
}

\author{
S. Archana* , B. Sundaramoorthy and M. Mohamed Faizullah
}

Dr. M.G.R. Fisheries College and Research Institute, Tamilnadu Dr. J. Jayalalithaa Fisheries University, India

*Corresponding author

\begin{abstract}
A B S T R A C T
Keywords

Aquaculture, Antifouling paint, Fouling, Coating, Non-coating, Infrastructures

Article Info

Accepted:

26 December 2018

Available Online:

10 January 2019

The biofouling issue is a tenacious issue throughout the history of aquaculture farming in the world, however it has elevated in priority as labour and electricity costs have arisen in recent years. Besides, fouling development is frequently fast on the grounds that the waters encompassing aquaculture activities are enhanced by natural and inorganic squanders (uneaten food, fecal and excretory material) created by high-density fish populations. The large surface area and structure of mesh material, especially multifilament mesh, is exceptionally appropriate for colonization and development of fouling. Biofouling of fishcage netting is a critical operational issue to aquaculture. The occlusion of mesh and the subsequent limitation in water exchange adversely influences fish health by the reduction in dissolved oxygen (DO) and the accumulation of metabolic ammonia. Fouling is also reducing the cage floatation, cage deformation, increases structural fatigue, and may go about as a supply for pathogens. The effects of fouling differ significantly relying upon season and area, and are additionally impacted by cultivating techniques and practices. The impacts of these factors are reviewed and highlighted. Suggesting an effective biofouling control will help to develop non- toxic coating particularly suited for aquaculture applications in future.
\end{abstract}

\section{Introduction}

Any artificial or natural substance get in contact with water environment become colonised by marine organisms, a process which is called biofouling (Railkin, 2004). Within minutes of immersion, a surface becomes 'conditioned' through the adsorption of macromolecules such as proteins, present in the water. Bacteria colonise within hours as may unicellular algae, protozoa and fungi. These early colonisers form a biofilm, which is an assemblage of attached organisms that is often referred to as microfouling or slime serve as a base for the growth of macrofouling, which consists of seaweed, and invertebrates such as barnacles, mussels, ascidians and hydroids.

Now a day, biofouling is a major biosecurity risk for the aquaculture industry, which includes direct impacts on cultures species (e.g. smothering, competition for space and food), deterioration of farm infrastructure (immersed structures such as cages, netting and pantoons) and effects on natural ecosystem functioning of adjacent areas. 
The production infrastructure for the species in variably consists of a complex assortment of submerged components with aerators, pipes, cages, nets, floats and ropes. All of these structures serve as surfaces for biofouling. The presence of such varied surfaces provides for a broad diversity of epibiotic organisms to settle and grow. These marine algae and animals, are severely problematic to culture operations and can have significant economic impacts. Conservative estimates of around $5-10 \%$ is attributed to biofouling which directly affects the economic costs of control in aquaculture (Lane Willemsen, 2004). Globally, this equates to costs of US\$ 1.5 to 3 billion/yr. To minimize these impacts, the aquaculture industry uses technologies to manage and control fouling communities.

The composition of fouling communities and their effect in marine aquaculture is largely dictated by the properties of the fouling surface, and the protection and management of these surfaces is the key to biofouling control. Currently there is a substantial amount of information on the mechanisms of biofouling and an array of options are available that have shown promise in combating the problem for specific marine applications, eg ship and boat fouling prevention, electricity generator coolant water intake pipes, bivalve aquaculture structures in inshore waters, fish cage farms. Biofouling on marine pond farms has received little, if any, attention so that currently the primary means of dealing with fouling is manual cleaning. The approach taken to control biofouling is regular manual defouling as required and it is anticipated that a preventative approach would be more cost effective and reliable and provide significant farm management benefits. A broad range of antifouling options are now commercially available or being developed, including: - chemical, biological, electrical, ultrasound irradiation, surface microtexture, novel materials approaches. The use of biocidal coatings with persistent or broadly toxic active ingredients, such as copper or organic toxins, may have govt. approval issues for the enclosed or semienclosed water bodies of marine pond farms and is not a preferred option for farmers. So prevention of biofouling using eco-friendly method is suggesting control options for aquafarm.

\section{Impacts of biofouling in aquaculture structures}

Biofouling is a significant issue for all forms of aquaculture operating in the marine and brackish water environment for aquaculture activities such as shellfish and finfish farming. The culture structures used for both and in the case of shellfish, the hard shell of the animals themselves, are severely impacted by biofouling and the industries need to employ a variety of approaches to control production limiting affects. A survey of shellfish culture operations in the USA put the cost of controlling biofouling at $14.7 \%$ of total operating costs (Adams, et al., 2011). Manual cleaning of fish cages and shellfish structures continues to be the most common control measure (Adams, et al., 2011). Biofouling is a specific problem in aquafarms mainly damaging the infrastructures and major key impacts are restricting the water exchange, increase disease risk and causes deformation of structures (Fitridge., et al 2012). Biofouling adds significant weight and drag to shell fish culture infrastructure, rapidly becoming a management issue.

The Effect of Biofouling in aeration devices rises the cost of production through electricity consumption, increased maintenance cost and labour cost. It has been estimated that the current drawn by paddle wheels can be up to $50 \%$ greater when heavily fouled. One farm estimated that on average across the farm 
power consumption was increased by $20 \%$ and $50 \%$ extra maintenance and repair cost due to fouling. Aerator surfaces that are typically subject to fouling are generally stainless steel and plastic. By far the greatest wetted surface area of paddlewheels and other aerators are plastics, particularly high density polyethylene (HDPE) which is used to construct the floats and the motor cover. HDPE has some inherent fouling control properties as a result of its surface characteristics but this does not prevent colonization. Even under ideal conditions HDPE can only restrict the adhesive strength of foulants such as barnacles, tubeworms and algae. Biofouling reduce the efficiency of oxygen transfer in aquafarms (Mann, 2011). In the aquafarms, it is found that the fouling on cage netting greatly reduce the efficiency (Willemsen. 2003). The costs associated with biofouling can be very significant (Beaz et al., 2005). The replacement of nets is expensive, annual costs to replace nets and reapply antifouling for a medium-sized UK salmon farm is estimated to be $\pm € 120.000$. Biofouling growth on fish cages and infrastructure has three main negative effects:

Restriction of water exchange due to the growth of fouling organisms causing net occlusion. When fish are held in high density in net pens, this leads to poor water quality as flushing is reduced. Lowered dissolved oxygen levels result and the removal of excess feed and waste is inhibited;

Disease risk due to fouling communities acting as reservoirs for pathogenic microorganisms harboured by macro- or microbial fouling species on cage netting, or lowered dissolved oxygen levels from poor water exchange increasing the stress levels of fish, lowering immunity and increasing vulnerability to disease.

Cage deformation and structural fatigue due to the extra weight imposed by fouling. The maintenance and loss of equipment directly contributes to production costs for the industry.

Cleaning oyster cultures is estimated to be $20 \%$ of the market value and biofouling can reduce growth rates by over $40 \%$. The estimated cost of fouling on cultured mussels in Scotland is $\pm 450-750.000$ Euro per year for farmers, and the problem is worsening (Campbell and Kelly, 2002).

\section{Control of biofouling in aquaculture}

Unlike other industries where biofouling is a problem, such as shipping, few studies have examined the impact and sought costeffective solutions for the aquaculture industry. The most common methods to control the problem are mechanical cleaning or using antifouling coatings.

Mechanical cleaning, involving brushing, scraping or cleaning using water jets, is labour intensive and tedious (Hodson et al., 1997). Air/sun drying when nets or oysters are hoisted out of the water and desiccation or heat kills but does not remove fouling. Cleaning of shellfish can be combined with immersing the biofouled shellfish in either hot or fresh-water, chlorine, salt solution or lime (Arakawa, 1980). The stress of the immersion medium kills the fouling.

Applying a biocidal coating on the surface is still widely used in aquaculture. Net coatings are usually low-tech versions of coatings for vessels. Small amounts of the active substance are released to deter or kill the fouling. The lifetime of such coatings, mostly based on copper oxide $\left(\mathrm{Cu}_{2} \mathrm{O}\right)$, is limited to one season, while the costs for treating nets are high.

Antifoulants are known sources of pollution from aquaculture and are responsible for elevated levels of copper close to fish-farms. 
In addition to $\mathrm{Cu}_{2} \mathrm{O}$, organic biocides with improved environmental profiles (e.g. biodegradable) are available (Costello et al., 2001), but these are generally not targeted at the aquaculture industry. Fouling prevention strategies for culture equipment such as ropes, floats, panels, nets and trays have traditionally used heavy metals including copper, nickel and tin. Unlike tributyltin and nickel, copper based coatings remain in use despite their negative impacts on developing vertebrates and invertebrates (Oliva et al., 2007), and their ability to concentrate in shellfish tissues (Chang sheng et al., 1990). Environmental problems associated with commonly used biocides have led to increasingly restrictive legislation and the banning of some compounds for use on vessels and in aquaculture, most notably TBT (IMO, 2002) and in some member states copper, Irgarol and Diuron.

When fish net cages impregnated with toxic coatings do become fouled they need to be removed and cleaned. This costly process causes stress to the fish resulting in mortality (estimated at 2\%). Net washing plants have problems dealing with the copper containing waste and sludge. The waste must be specially disposed of and such safeguards evidently increase costs. Some other antifouling methods certainly exist, examples of which are biological control using grazers (Hidu et al., 1981; Lodeiros and Garcia, 2004); avoidance when cultures are removed or repositioned during periods of heavy fouling settlement (Rikard et al., 1996); new materials (coatings) such as silicone based fouling-release coatings (Baum et al., 2002), generally in combination with mechanical cleaning (Hodson et al., 2000) or coatings for netting (McCloy and De Nys, 2000; De Nys et al., 2004); new cage designs to limit fouling on shellfish or fish net cages (Menton and Allen, 1991); and spraying with an antifouling solution such as acetic acid
(Carver et al., 2003). These methods are only being used locally or are under development. Biofouling persists as a significant practical and economic barrier to the development of competitive aquaculture and there is a need for cost effective, sustainable solutions to the fouling problem. The antifouling sector, mainly fulfilling the needs of the shipping industry, has for decades undertaken a great deal of research into developing toxic and non-toxic antifouling strategies. Virtually none of this work has considered the specific needs and issues related to aquaculture. It will proof fruitful to utilize this knowledge base to develop sustainable and environmental benign approaches to reducing the biofouling problem within aquaculture.

\section{Natural antifouling methods}

The negative and significant impacts that biofouling has on viability and profitability of aquaculture has necessitated a long and persistent effort in biofouling control. Historically, the aquaculture industry has borrowed antifouling (AF) technologies from other marine industries which focus on chemical AF technologies. AF paints to control biofouling are commonly used on surfaces in marine transport, oil and gas industries (Yebra et al., 2004; de Nys and Guenther 2009; Durr and Watson 2010). These paints leach biocidal compounds such as heavy metals and organic biocides onto the surface, producing a thin, toxic layer which prevents the onset of biofouling. However, many of the chemicals and heavy metals involved are recognized as dangerous in the environment, with detrimental effects on the survival and growth of shellfish (Paul and Davies 1986; reviewed by Fent 2006) and fish (Lee et al., 1985; Short and Thrower 1986; Bruno and Ellis 1988) and this has prompted an effort to prevent or mitigate biofouling in aquaculture through alternative methods. 
Natural product antifoulants (NPAs) are globally accepted and one of the most promising environmentally benign option to control marine biofouling. After the ban of TBT based antifouling paints and environmental concerns associated with other toxic biocides, there is a growing need for the effective eco-friendly antifoulants for marine applications (Yanget al., 2007; Bao et al., 2013). Research interest on natural product antifoulants has been increased in the recent years that were evident from the growing number publications (Bao et al., 2013; Keifer, PA and KL. Renillafoulins Rinehart, 1986). In nature, many marine sessile organisms are keeping their surfaces free from fouling organisms (Renillafoulins Rinehart, 1986; Yang et al., 2006) mainly through the production of secondary metabolites (Hentschel et al., 2001, Pawlik et al., 2012). The secondary metabolites produced by many marine organisms that showed inhibitory activities against the biofouling organisms would be the ideal lead molecules for the development of natural product antifoulants that can be incorporated into paints (Clare, 1996, Feng et al., 2009).

The compounds belonging to terpenoids, steroids, carotenoids, phenolics, furanones, alkaloids, peptides and lactones extracted from the marine organisms showed antifouling activities (Feng et al,2009). Among the marine organisms, antifouling activities were largely reported from sponges and corals (Hellio et al., 2005; Limna mol et al., 2010; Dobrestov et al., 2015; Taylor et al., 2007). Sponges especially attracted the attention of the researchers due to their close relationship with wide variety of microbes and presence of large number of biologically active secondary metabolites (Taylor et al., 2007).Another important group attracted the attention of investigators is the ascidians from which good number of antifouling molecules were reported in the literature (Mayzel et al., 2014; Trepos et al., 2014). Antifouling activities were also reported from seaweeds, seagrasses, (De nys et al., 1995; Helio et al., 2002), bryozoans (Walls et al., 1993; Konyaet al., 1994), mangroves and microorganisms (Burgesset al., 1999; Kennedy et al., 2009; Satheesh et al., 2012; Viju et al., 2014).

Few antifouling coatings based on natural products from the marine organisms such as Sea Nine- 211, Netsafe and Pearlsafe have already been commercialized (Jacobson and Willingham, 2000; De Nys et al., 2004). During the past five decades' bioactive metabolites from the marine environment attracted the attention of researchers all over the world for the discovery of lead compounds in medicine and industry (Jones et al., 2007; Dunlap et al., 2007; Devi et al., 2010; Mayer et al., 2011; Felczy kowska et al., 2012; Cong et al., 2014; Cortes et al., 2014). Due to the concern on exploitation of large amount of marine organisms for natural products discovery, marine microbes are considered as the viable source for searching bioactive molecules. Many novel bioactive metabolites with antifouling activities were reported from marine microbes in the literature (Egan et al., 2002; Bhattarai et al., 2007; Bowman, 2007; Ortega-Morales et al., 2008; Soliey et al., 2011). Sessile soft-bodied marine organisms are having inherent antifouling property, i.e. they produce secondary metabolites as a chemical means of warfare, protection from predation, competition for space, prevention of over growth/ biofouling, combat poisoning and fight infections. Thus there is an intense research activity to seek novel, environmentally benign methods of fouling control. 


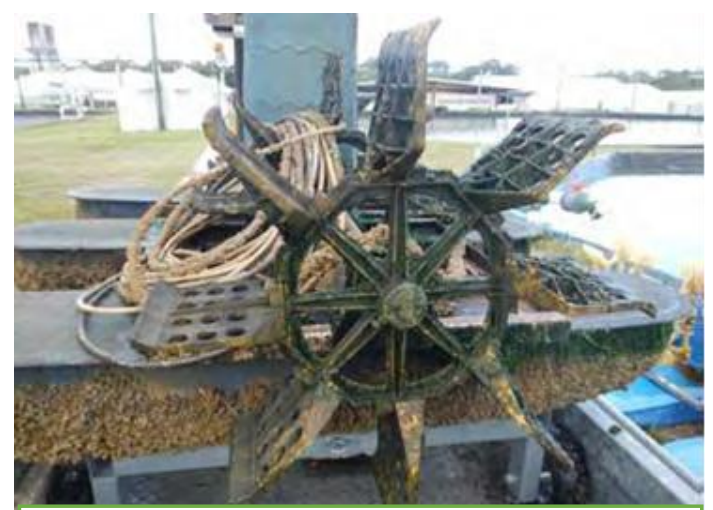

Biofouling in Paddlewheel aerator

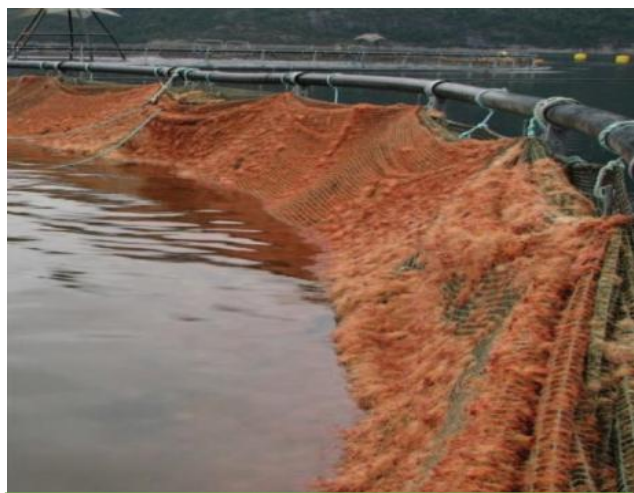

Biofouling in floating cage

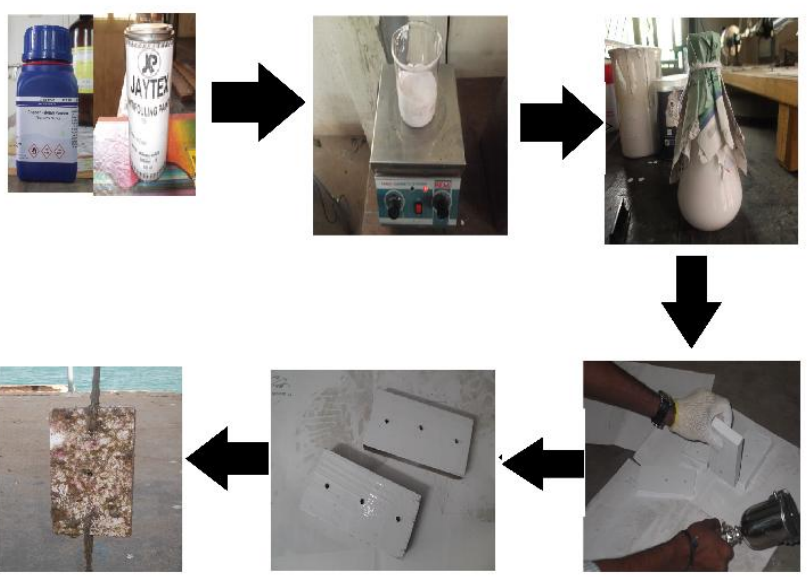

One of the antifouling technique (spray coating using copper) 


\section{Antifouling strategy/technology}
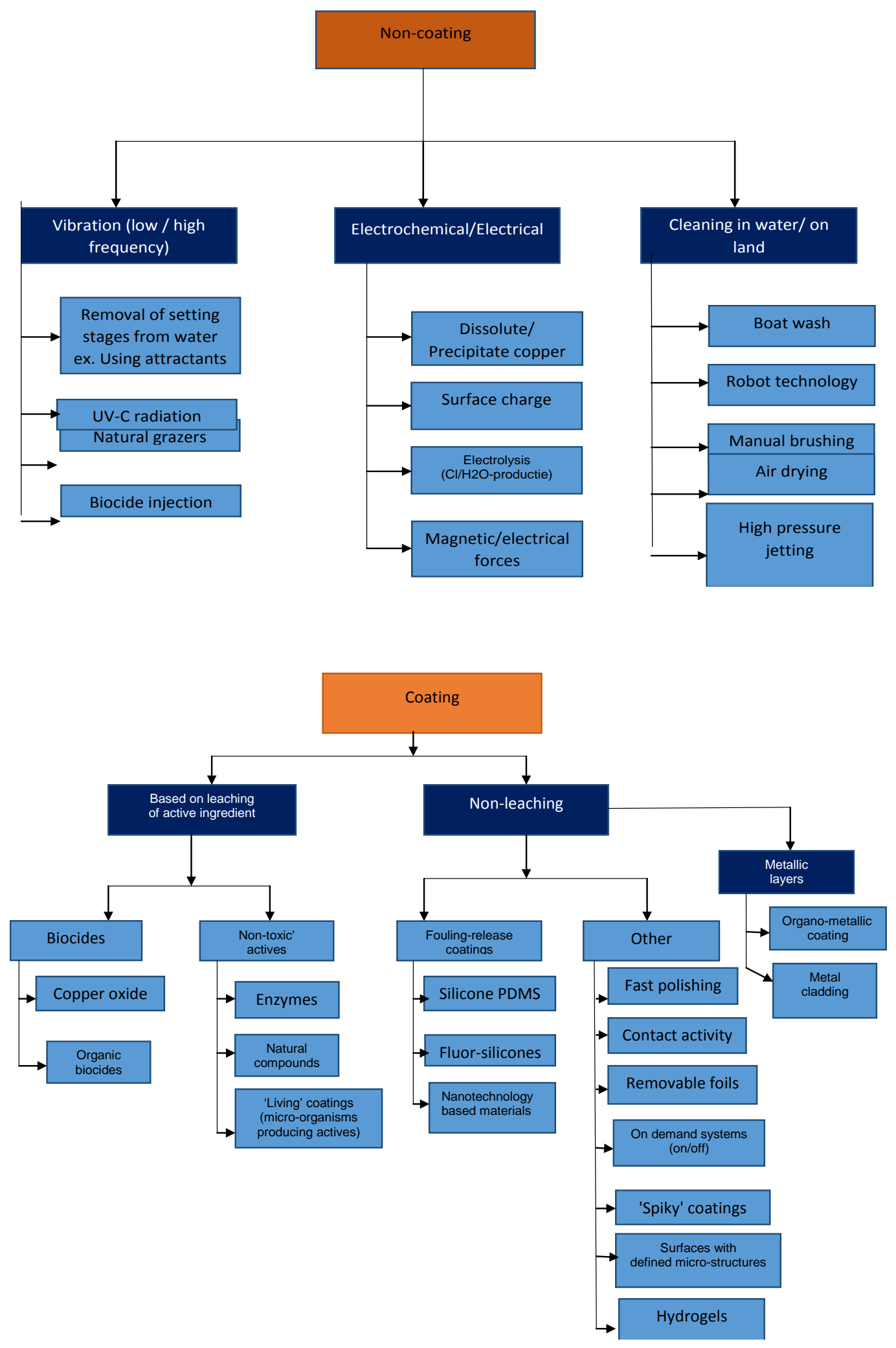
In conclusion the occurrence of biofouling in aquaculture is an important management issue resulting in increased operational expenses and detrimental impacts on the species being cultured. Surprisingly, for an issue with such high impact in a growing global industry, scanty information exists on its effects and costs. The expansion of tropical aquaculture and the trend towards greater use of offshore sites both present new challenges in understanding the impacts of fouling and implementing successful control measures. Given the limited choice of products currently available, quantitative studies on the spatial and temporal variation of fouling species, and farm management on fouling development, are essential to assist the industry to choose the most cost effective and practical methods for fouling control, both now and into the future. In terms of control, the mechanical removal of biofouling remains dominant in shellfish and fish culture, and copper coatings on fish nets are the only consistently effective form of biofouling prevention at an industrial scale. Further developments need to rely of incremental improvements in these technologies by effective environmentally benign method of control biofouling in aquaculture. Using of biocides as an antifouling is making organisms to suffer in many ways instead of that environmentally benign antifouling method is more valuable for aquaculture farm industries. Therefore, while the aquaculture industry remains a step behind other maritime industries in control methods it can also benefit from the broader research effort across maritime industries to solve a cosmopolitan, persistent and complex problem, biofouling.

\section{References}

Adams, CM., Shumway S.E. Whitlach R.B, and Getchis. T, 2011. Biofouling in marine molluscan shellfish aquaculture: a survey assessing the business and economic implications of mitigation. J World Aquacult Soc, 42: 242-252.

Arakawa, K, 1980. Prevention and removal of fouling on cultured oysters: a handbook for growers. Maine Sea Grant Technical Report No. 56.

Bao, J., YL. Sun, XY. Zhang, Z. Han, HC. Gao, and He. F, 2013 Antifouling and antibacterial polyketides from marine gorgonian coral-associated fungus Penicillium sp. SCSGAF0023. J Antibiot. 66:219 - 23.

Beaz. D., V. Beaz, S. Dürr, J. Icely, A. Lane, J. Thomason, D. Watson, and Willemsen, P.R, 2005. Sustainable Solutions for Mariculture Biofouling in Europe. ASLO Meeting, Santiago da Compostela, Spain.

Bhattarai, HD., V.S. Ganti, B. Paudel, Y.K. Lee, H.K. Lee, and Hong. Y.K. 2007. Isolation of antifouling compounds from the marine bacterium, Shewanella oneidensis SCH0402. World J Microbiol Biotechnol. 23:243-9.

Bowman, JP. 2007. Bioactive compound synthetic capacity and ecological significance of marine bacterial genus Pseudoalteromonas. Mar Drugs. 5:220-41.

Bruno, D.W. and Ellis. A.E, 1988. Histopathological effects in Atlantic salmon, Salmo salar L., attributed to the use of tributyltin antifoulant. Aquaculture 72:15-20

Burgess, JG., Jordan, E. M Bregu, M. A. Mearns-Spragg, and Boyd K.G. 1999. Microbial antagonism: A neglected avenue of natural products research. $J$ Biotechnol. 70:27 - 32

Campbell, D.A. and Kelly M.S, 2002. Settlement of Pomatoceros triqueter (L.) in two Scottish Lochs, and factors determining its abundance on mussels grown in suspended culture. $J$ 
Shellfish Res, 21: 519-527.

Carver, C.E.,A. Chisholm, and. Mallet. A.L., 2003. Strategies to mitigate the impact of Ciona intestinalis (L.) biofouling on shellfish production. J Shellfish Res, 22:621-631.

Clare, A.S. 1998. Towards non-toxic antifouling. J Mar Biotechnol 6:3.

Clare, AS.,1996. Marine natural product antifoulants: Status and potential. Biofouling. 9:211-29

Cong, L., W. Liang, Y. Wu, C. Li, Y. Chang, and Dong. L. 2014. High-level soluble expression of the functional peptide derived from the $\mathrm{C}$-terminal domain of the sea cucumber lysozyme and analysis of its antimicrobial activity. Electron J Biotechnol. 17: 280 - 286.

Cortés, Y., E. Hormazábal, H. Leal, A. Urzúa, A. Mutis, and Parra. L., 2014. Novel antimicrobial activity of a dichloromethane extract obtained from red seaweed Ceramium rubrum (Hudson) (Rhodophyta:

Florideophyceae) against Yersinia ruckeri and Saprolegnia parasitica, agents that cause diseases in salmonids. Electron $J$ Biotechnol. 17:126-31.

Costello, M.J.,A. Grant,I.M, Davies, S. Cecchini,S. Papoutsoglou,D.Quigley, and M. Saroglia, M (2001) The control of chemicals used in aquaculture in Europe. $J$ Appl Ichthyol., 17:173-180.

De Nys, R and Ison. O, 2004. Evaluation of antifouling products developed for the Australian pearl industry. Fisheries Research and Development Corporation; 2004. Cooper EL. Drug discovery, CAM and natural products. Evid Based Complement Alternat Med. 1:215-7.

De Nys, R. and Guenther. J. 2009. The impact and control of biofouling in marine finfish aquaculture. In: Hellio C,
Yebra D, editors. Advances in marine antifouling coatings and technologies. Cambridge (UK): Woodhead Publishing Ltd. p. 177-221.

De Nys, R. and Ison, O. 2004. Evaluation of antifouling products developed for the Australian pearl industry. Project No 2000/254. Final Report to the Fisheries Research and Development Corporation. Townsville (Q1d): James Cook University. 114 pp.

De Nys, R., PD. Steinberg, P. Willemsen, SA. Dworjanyn, CL. Gabelish, and King. RJ, 1995. Broad spectrum effects of secondary metabolites from the red algae Delisea pulchra in antifouling assays. Biofouling. 8: 259-71.

De Nys, R.C., P. Steinberg, T.S. Charlton, and Christov. V. 2004. Antifouling of shellfish and aquaculture apparatus. Unisearch Limited, US, p 32.

Devi, P., S. Wahidullah, C. Rodrigues, and Souza. LD. 2010. The Spongeassociated bacterium Bacillus licheniformis SAB1: A source of antimicrobial compounds. Mar Drugs. $8: 1203-12$.

Dobretsov, S., ASM. Al-Wahaibi, D. Lai, J. Al-Sabahi, M. Claereboudt, and Proksch. P. 2015. Inhibition of bacterial fouling by soft coral natural products. Int Biodeterior Biodegrad. 98:53-8.

Dunlap, W.C., CN. Battershill, CH. Liptrot, RE. Cobb, DG. Bourne, and Jaspars.. M 2007. Biomedicinals from the phytosymbionts of marine invertebrates: A molecular approach. Method.42:358 -76.

Durr, S. and Watson. D.I 2010. Biofouling and antifouling in aquaculture. In: Durr S, Thomason JC, editors. Biofouling. Oxford (UK): WileyBlackwell. p. 267-287.

Egan, S., S. James, C. Holmström, and Kjelleberg. S, 2002. Correlation 
between pigmentation and antifouling compounds produced by Pseudoalteromonas tunicate. Environ Microbiol. 4:433.

FAO. 2010. The state of world fisheries and aquaculture, Food and Agriculture Organization of the United Nations.

Felczykowska, A., SK. Bloch, B. NejmanFaleńczyk, and Barańska. Metagenomic, S.2012. approach in the investigation of new bioactive compounds in the marine environment. Acta Biochim Pol. 59: $501-5$.

Feng, D., C. Ke, S. Li, C. Lu, and Guo. F, 2009. Pyrethroids as promising marine antifoulants: Laboratory and field studies. Mar Biotechnol. 11: 153-60.

Fent, K. 2006. Worldwide occurrence of organotins from antifouling paints and effects in the aquatic environment. In: Konstantinou I, editor. Antifouling paint biocides. The Handbook of Environmental Chemistry 5.0. Berlin (Germany): Springer-Verlag. p. 71100.

Fitridgea, I., T. Dempstera, J. Guentherb, and de Nysc, R. 2012. The impact and control of biofouling in marine aquaculture: a review. Biofouling, 28 (7): 649-669.

Hellio, C., J.P. Bergé, C. Beaupoil, Y. Le Gal, and Bourgougnon. N.2002. Screening of marine algal extracts for antisettlement activities against microalgae and macroalgae. Biofouling. 18:205 -15.

Hellio, C., M. Tsoukatou, J. Marechal, N. Aldred, C. Beaupoil, and. Clare. A.S. 2005. Inhibitory effects of Mediterranean sponge extracts and metabolites on larval settlement of the barnacle Balanus amphitrite. Mar Biotechnol. 7:297-305.

Hentschel, U., M.S. chmid, M. Wagner, L. Fieseler, C. Gernert, and Hacker. J.
2001. Isolation and phylogenetic analysis of bacteria with antimicrobial activities from the Mediterranean sponges Aplysina aerophoba and Aplysina cavernicola. FEMS Microbiol Ecol. 35:305-12.

Hidu, H., C. Conary, and Chapman. S.R. 1981. Suspended culture of oysters: biological fouling control. Aquaculture, 22:189-192.

Hodson, S.L.,C.M, Burke, and Bissett. A.P. 2000. Biofouling of fishcage netting: the efficacy of a silicone coating and the effect of netting colour. Aquaculture, 184:277-290

Hodson, S.L.,T.E, Lewis, and Burke. C.M. 1997. Biofouling of fishcage netting: efficacy and problems of in situ cleaning. Aquaculture, 152:77-90.

IMO. International Maritime Organization, Antifouling Systems.

Jacobson, A.H. and Willingham. G.L. 2000. Sea-nine antifoulant: An environmentally acceptable alternative to organotin antifoulants. Sci Total Environ. 258:103-10.

Jones, P., M.T. Cottrell, DL. Kirchman, and Dexter. S.C, 2007. Bacterial community structure of bio films on artificial surfaces in an estuary. Microb Ecol. 53:153-62.

Keifer, PA. and Renillafoulins Rinehart, K.L. 1986. Antifouling diterpenes from the sea pansy Renilla reniformis (Octocorallia). J Org Chem. 51:4450 4.

Kennedy, J., P. Baker, C. Piper, P.D. Cotter, M. Walsh, M.J, and Mooij.2009. Isolation and analysis of bacteria with antimicrobial activities from the marine sponge Haliclona simulans collected from Irish waters. Mar Biotechnol. 11: 384 - 96.

Kon-ya, K., N. Shimidzu, and Adachi Miki.W, $1994 . \quad$ 2,5,6-Tribromo-1methylgramine, an antifouling 
substance from the marine bryozoans Zoobrotryon pellucidum. FishSci. 60:773-5

Lane,A. and Willemsen. P.R, 2004. Collaborative effort looks into biofouling. Fish Farming Int 2004: 34-35.

Lee, H.B., L.C, Lim, and Cheong. L, 1985. Observations on the use of antifouling paint in net cage fish farming in Singapore. Singapore J Primary Ind 13:1-12.

Limna Mol, V.P., TV. Raveendran, K.R. Abhilash, and. Parameswaran. P.S. 2010. Inhibitory effect of Indian sponge extracts on bacterial strains and larval settlement of the barnacle, Balanus amphitrite. Int Biodeterior Biodegrad. 64:506 -10.

Lodeiros, C. and Garcia. N. 2004. The use of sea urchins to control fouling during suspended culture of bivalves. Aquaculture, 231: 293-298.

Mann, K.V. 2011. Theoretical perspectives in medical education: past experience and future possibilities. Med Educ., 45(1):60-80.

Mayer, A.M.S., A.D. Rodríguez, R.G.S. Berlinck, and Fusetani., N, 2011. Marine pharmacology in2007-8: Marine compounds with antibacterial, anticoagulant, antifungal, antiinflammatory, antimalarial, antiprotozoal, antituberculosis, and antiviral activities; affecting the immune and nervous system, and other miscellaneous mechanisms of action. Comp Biochem Physiol Part C: Toxicol Pharmacol 153:191 -222.

Mayzel, B., M. Haber, and. Ilan. M, 2014. Chemical defense against fouling in the solitary ascidian Phallusia nigra. Biol Bull. 227:232-41.

McCloy, S. and De Nys. R. 2000. Novel Technologies for the reduction of biofouling in shellfish aquaculture. In:
Fisheries N (ed) Flat Oyster Workshop, Sydney, p 19-23.

Menton, D.J. and Allen. J.H. 1991. Spherical (Kiel) and square steel cages: first year of comparative evaluations at $\mathrm{St}$ Andrews, NB. Bull Aquacult Assoc Canada, 91:111-113.

Oliva, M., M.D, Carmen Garrido Perez, E. Gonzalez De, and Canales. M.L, 2007. Evaluation of acute copper toxicity during early life stages of gilthead, Sparus aurata. J Environ Sci Health A 42:525-533.

Ortega-Morales, B.O., M.J. Chan-Bacab, E. Miranda-Tello, M.L. Fardeau, J.C. Carrero, and Stein. T, 2008. Antifouling activity of sessile bacilli derived from marine surfaces. $J$ Ind Microbiol Biotechnol 35:9-15.

Paul, J.D. and, Davies. I.M, 1986. Effects of copper and tin-based antifoulant on the growth of cultivated scallops (Pecten maximus) and oyster (Crassostrea gigas). Aquaculture, 54: 191-203.

Pawlik, J. R., 2012. Antipredatory defensive roles of natural products from marine invertebrates. In: E. Fattorusso, WH. Gerwick, and O. Taglialatela-Scafati, editors. Handbook of marine natural products. NY: Springer. $677-710$.

Railkin, AI. 2004. Marine biofouling: colonization process and defenses. ISBN 0-8493-1419-4. CRC Press

Ribeiro. SM., R. Rogers, AC. Rubem, BAP. Da Gama, G. Muricy, and Pereira. RC. 2013. Antifouling activity of twelve demo sponges from Brazil. Braz $J$ Biol. 73:501-6

Rikard, F.S.and R.K, Wallace and Nelson, C.L, 1996. Management strategies for fouling control in Alabama oyster culture. J Shellf Res, 15:529

Satheesh, S., A.R. Soniyamby, C.V. Sunjaiy Shankar, and Punitha. S.M.J, 2012. Antifouling activities of marine 
bacteria associated with the sponge (Sigmodocia sp). J Ocean Univ China. 11:354- 60 .

Sera, Y., K. Adachi, F. Nishida, and Shizuri. $\mathrm{Y}, 1999$. A new sesquiterpene as an antifouling substance from a Palauan marine sponge, Dysidea herbacea. $J$ Nat Prod. 62: 395 - 6.

Short, J.W. and Thrower, F.P, 1986. Accumulation of butyltin in mussel of Chinook salmon reared in sea pens treated with tri-n-butyltin. Mar Pollut Bull, 17:542-545

Soliev, AB., K. Hosokawa, and Enomoto. K, 2011. Bioactive pigments from marine bacteria: Applications and physiological roles. Evid Based Complement Alternat Med. 2011:117.

Taylor, MW., R. Radax, D. Steger, and Wagner. M, 2007. Sponge-associated microorganisms: Evolution, ecology, and biotechnological potential. Microbiol Mol Biol Rev. 71:295-47.

Trepos, R., G. Cervin, C. Hellio, H. Pavia, W. Stensen, and Stensvåg. K, 2014. Antifouling compounds from the subarctic ascidian Synoicum pulmonaria: Synoxazolidinones $\mathrm{A}$ and $\mathrm{C}$, pulmonarins $\mathrm{A}$ and $\mathrm{B}$, and synthetic analogues. J Nat Prod.77: $2105-13$.

Viju, N., A. Anitha, S. Sharmin Vini, CV. Sunjaiy Shankar, S. Satheesh, Punitha.
SMJ, 2014. Antibiofilm activities of extracellular polymeric substances produced by bacterial symbionts of seaweeds. Indian J Geo-Mar Sci. 43:1 $-11$

Wahl, M., PR. Jensen, and Fenical. W, 1994. Chemical control of bacterial epibiosis on ascidians. Mar Ecol Prog Ser. 110:45 - 57 .

Walls, JT., DA. Ritz, and Blackman. AJ. 1993. Fouling, surface bacteria and antibacterial agents of four bryozoans' species found in Tasmania, Australia. J Exp Mar Biol Ecol. 169:1-13.

Yang, L.H., L. Miao, O.O.Lee, X.Li, H.Xiong, and Pang. K.L., 2007. Effect of culture conditions on antifouling compound production of a spongeassociated fungus. Appl Microbiol Biotechnol. 74:1221-31

Yang, L.H., OO.Lee, T.Jin, X.C.Li, and Qian, P.Y. 2006. Antifouling properties of $10 \beta$-formamidokalihinol-A and kalihinol A isolated from the marine sponge Acanthella cavernosa. Biofouling. 22:23-32.

Yebra, D.M.,S. Kiil, and. Dam-Johansen. K, 2004. Antifouling technology - past, present and future steps towards efficient and environmentally friendly antifouling coatings. Prog Org Coat 50: $75-104$.

\section{How to cite this article:}

Archana, S., B. Sundaramoorthy and Mohamed Faizullah, M. 2019. Review on Impact of Biofouling in Aquafarm Infrastructures. Int.J.Curr.Microbiol.App.Sci. 8(01): 2942-2953. doi: https://doi.org/10.20546/ijcmas.2019.807.365 